\title{
Redefining the Success of Education: Where Indonesia has Excelled and Where It has Not
}

\author{
Henry Wijaya \\ Department of Indonesian Language and Culture, \\ Guangdong University of Foreign Studies, China \\ Email: henrywijaya@outlook.com
}

\begin{abstract}
How do we define the state of Indonesia's national education? On one hand, Indonesian students have always performed lamentably in international standardized tests. In the latest 2015 PISA test, their performance in Science, Mathematics, and Reading was among the lowest, with the average ranking of 62 out of the 70 participating countries (OECD, 2016). On the other hand, Indonesia's enrollment rates for primary education have always been higher than $97 \%$ for the past decade (Statistics Indonesia, 2018), with the Gross Enrollment Ratio even reaching $103.45 \%$ in 2016 (World Bank, 2016). With such polarizing results, it is not easy to give a clear-cut answer to above question. However, in retrospect, should the success of Indonesia's education be measured merely by numbers, in isolation from how it could socioculturally and politically impacted its citizens? Multiple societal tensions, as well as the looming 2019 election, should actually inform us how education should and could play a larger role in countering currently growing conservatism. This paper will first lay out multiple facets of Indonesia's national education - examining whether one area has fared better than the others - before making a case for the other role that Indonesia's education policy has not yet pondered, let alone incorporated. Ultimately, this paper expects to contribute to the wider discussion of the overarching question: how the success of national education should be (re-)defined.
\end{abstract}

Keywords: comparative education; education policy; peace education

\section{INTRODUCTION}

Is there anything that other countries should take notice of from Indonesia's experiences in the field of education? After all, unfavorable reports, disappointing news, and scathing criticisms have surfaced more often than positive ones when it comes to Indonesia's education.

Pisani-a longtime observer of Indonesia, a journalist, and a writer-wrote two provoking articles in 2013, titled Indonesian kids don't know how stupid they are and $A$ nation of dunces, followed by yet another exasperating piece in 2016, titled Apparently, 42\% of young Indonesians are good for nothing. As infuriating as they may, her accusations were not without reason. Pisani made such a seething remark as she cited the poor results of Indonesian students in an international standardized test, PISA (the test results from which she drew her conclusion will be discussed in details below).

However, although the drawbacks in some areas are tangible, some progresses are worthy of further examination. Hence, to find out what can be noted from Indonesia's national education, it is first necessary to understand its current condition.

Nonetheless, how do we define the state of Indonesia's national education? On one hand, its students have always performed lamentably in international standardized tests, such as PISA or TIMSS. On the other hand, Indonesia has scored remarkable multiple indicators, such as its Gross Enrollment Ratio or StudentTeacher Ratio. With such polarizing results, it is not easy to give a clear-cut answer to above question. 
Furthermore, in retrospect, should the success of Indonesia's education be measured merely by numbers, in isolation from how it could socioculturally and politically impacted its citizens? Incidents which took place in May 2018 in Jakarta, East Java, and Riau have shown that Indonesia is not yet free from the threat of terrorism stemming from religious radicalization. Besides, Indonesia's recent political atmosphere has arguably been clouded by racial and religious tensions, perhaps best illustrated by the last Jakarta's governor election, when the Chinese-Indonesian and Christian incumbent, Basuki Tjahaja Purnama - popularly known as Ahok - lost to the more "pribumi" (native) and Islamic contender, Anies Baswedan. Despite many people's ardent call to focus on programs and merits, it was proven that social division by race and religion is still very powerful weapon to gain political authority. Albeit sociocultural and political, that situation is arguably not unrelated to education and its potential impacts. Such cases, as well as the looming 2019 presidential election, should actually inform us on how education should and could play a larger role in an unpeaceful and divisive society.

This paper will first lay out multiple facets of Indonesia's national education-examining whether one area has fared better than the others-before making a case for the other role of education that Indonesian educators and policy makers have not yet pondered, let alone incorporated. Thus, this paper unfolds by following this structure: 1) how Indonesia's education measured through its students' performance in different international standardized tests, 2) how it could be measured through multiple economic indicators, and 3) how it could play another pivotal role in building a more cohesive and peaceful nation.

Utilizing mixed methods, different methods are applied to different parts of the study. Firstly, quantitative study was utilized to analyze different statistical data, namely performances in international tests and education indicators. Meanwhile, literature review was used to elucidate the concept of education as a peacekeeping or nation-building mean.

Some notes should be made in regard to the scope and limitation of this study. First of all, in relation to international test, this study only includes results from two tests, namely PISA and TIMSS (explained further below) as Indonesia participates in these two tests regularly. Secondly, in relation to education indicators, this study only includes results up to secondary education (middle and high school in Indonesia), as it is generally accepted that tertiary education (or university education, not to be confused with senior high school) is not compulsory and hence, government usually plays little or limited role in its funding and development, and therefore, does not usually significantly affect its standing nor achievement.

Ultimately, this paper expects to contribute to the wider discussion of the overarching question: how the success of national education should be (re-)defined.

\section{FINDINGS AND DISCUSSION \\ Through the Lens of International Standardized Tests}

One way to compare the quality of one country's education to the others' is by looking at their students' performance in international standardized tests. This paper will only discuss the results of two tests, namely the Programme for International Student Assessment (PISA) and the Trends in International Mathematics and Science Study (TIMSS), since Indonesia takes part in these two tests more regularly.

\section{Indonesia in PISA 2015}

The Programme for International Student Assessment (PISA) is conducted every three years by the Organisation for Economic Co-operation and Development (OECD). With 35 countries as its member, OECD aims at promoting policies that will improve the economic and social wellbeing of people around the world (OECD, 2018). To achieve its mission, OECD analyze and compare data to predict future trends, as well as setting international standards on a wide range of fields, including education (OECD, 2018).

The last PISA test was administered in fall 2018. Unfortunately, since the results of PISA 2018 will not be available until December 2019, its data cannot be included and used in this paper. Therefore, this paper resorts to the results of the previous test, PISA 2015, whose results were made available for public in December 2016.

According to OECD (2016), "PISA assesses the extent to which 15-year-old students, near the end of their compulsory education, have acquired key knowledge and skills that are essential for full participation in modern societies" (p. 25). Thus, it is ascertained that PISA does not only examine whether students can reproduce knowledge, but whether they can also extrapolate from what they have learned and apply those in multiple settings. PISA generally examines three core subjects, namely Reading, Mathematics, and Science, although the latest 2015 PISA also assesses collaborative problem-solving proficiency.

In fact, the Indonesian students' performance in PISA was what Pisani $(2013 ; 2016)$ has used as basis 
to harshly criticize the quality of Indonesia's education (Refer to Par. 1-2 above).

Table 1. Indonesian Students' Performance in PISA 2015

\begin{tabular}{|l|c|c|c|}
\hline & Reading & Math & Science \\
\hline Top Achiever & 535 & 564 & 556 \\
\hline PISA Average & 493 & 490 & 493 \\
\hline Indonesia & $\begin{array}{c}397 \\
(64 / 70)\end{array}$ & $\begin{array}{c}386 \\
(63 / 70)\end{array}$ & $\begin{array}{c}403 \\
(62 / 70)\end{array}$ \\
\hline Lowest Achiever & 347 & 328 & 332 \\
\hline
\end{tabular}

Note: Number in the brackets indicates the rank of Indonesia out of the total participants. Source: OECD (2016)

Table 2. Indonesian Students' Performance in PISA 2015 in Comparison to SEA's

\begin{tabular}{|l|c|c|c|}
\hline & Reading & Math & Science \\
\hline Singapore & $535(1)$ & $564(1)$ & $556(1)$ \\
\hline Vietnam & $487(32)$ & $495(22)$ & $525(8)$ \\
\hline Thailand & $409(57)$ & $415(54)$ & $421(54)$ \\
\hline Indonesia & $397(64)$ & $386(63)$ & $403(62)$ \\
\hline
\end{tabular}

Note: Number in the brackets indicates the rank of that particular score. Source: OECD (2016)

As visible from Table 1 above, the performance of Indonesian students in the three core subjects are all below par. With the scores of 397 for Reading, 386 for Mathematics, and 403 for Science, Indonesian students are near the bottom, ranking 64, 63, and 62 respectively, out of 70 participating countries.

With such low scores, Indonesian students have also placed themselves below students from other Southeast Asian countries, such as Singapore, Vietnam, and Thailand (See also Table 2 above). In fact, Singapore is the top performers in all the three subjects.

In Reading, Indonesian students only managed to score 397 (ranked $64^{\text {th }}$ ), whereas their neighboring peers from Thailand, Vietnam, and Singapore scored 409 $\left(57^{\text {th }}\right), 487\left(32^{\text {nd }}\right)$, and $535\left(1^{\text {st }}\right)$ respectively. Meanwhile in Mathematics, the scores are not far different. Only managed to score 386 to get themselves to the $63^{\text {rd }}$ rank, Indonesian students are below those from Thailand $\left(415 / 54^{\text {th }}\right)$, Vietnam $\left(495 / 22^{\text {nd }}\right)$, and Singapore $\left(564 / 1^{\text {st }}\right)$. Lastly, in Science, with the score which is slightly higher of 403 and the rank of $62^{\text {nd }}$, Indonesian students' results are still below $421\left(54^{\text {th }}\right)$ of Thailand, $525\left(8^{\text {th }}\right)$ of Vietnam, and $556\left(1^{\text {st }}\right)$ of Singapore.
Looking at these results, it can be said that Indonesian students have indeed performed disappointingly at PISA test.

\section{Indonesia in TIMSS 2015}

Another international standardized test that could be utilized to evaluate students' performances is the Trends in International Mathematics and Science Study (TIMSS), which is sponsored by the International Association for the Evaluation of Educational Achievement (IEA). IEA is a nonprofit and independent organization, consisting of national research institutions, government research agencies, scholars and analysts who work together as an international cooperative in order to evaluate, understand, and improve education globally (IEA, 2018a). More than 60 countries have been actively involved in its network, while over 100 education systems have participated in its studies (IEA, 2018a). Using its quasi-longitudinal design, TIMSS measures students' Mathematics and Science achievement while they are in their fourth and eighth grade (IEA, 2018). The latest TIMSS was administered in 2015, while the next one will be in 2019 .

Table 3. Performance of 4th-Grade Indonesian Students in TIMSS 2015

\begin{tabular}{|l|c|c|}
\hline & Mathematics & Science \\
\hline $\begin{array}{l}\text { Top Performer } \\
\text { (Singapore) }\end{array}$ & 618 & 590 \\
\hline Indonesia & $397(44 / 49)$ & $397(44 / 47)$ \\
\hline $\begin{array}{l}\text { Lowest Performer } \\
\text { (Kuwait) }\end{array}$ & 353 & 337 \\
\hline
\end{tabular}

Note: Only 4th-grade Indonesian students were tested in TIMSS 2015. Source: Mullis, Martin, \& Hooper (2016)

As can be seen in Table 3 above, the Indonesian students' performance in TIMSS was also substandard. From 49 participants in the Mathematics test and from 47 in the Science test, they only managed to rank 44th in both. In comparison, Singapore students - as the top performer-scored 618 in Mathematics and 590 in Science, whereas Kuwait - as the lowest performeronly scored 353 and 337 in Mathematics and Science respectively.

Unfortunately, the Indonesian students' performance cannot be viewed in comparison to students from neighbor countries, since only Singapore students participated in TIMSS 2015. All in all, what the Indonesian students had achieved in TIMSS were not satisfactory either. 
Hence, when evaluated through this parameter, it is obvious that the Indonesian government hast still got huge homework in this area.

\section{Through Education Indicators}

Nevertheless, not all about Indonesia's education are bitter and sour. Since its independence in 1945, Indonesian government, through its Kementerian Pendidikan dan Kebudayaan (the Ministry of Education and Culture, referred as MoEC hereafter), has actually made some noteworthy progresses. These could be viewed through multiple education indicators presented below.

\section{Participation Rate in Primary Education}

Participation rate could become one of the benchmarks to evaluate a country's success in providing national education service. The first measurement of participation rate that we could check is the Gross Enrollment Rate (GER).

According to UIS (2018a) GER reflects the "number of students enrolled in a given level of education, regardless of age, expressed as a percentage of the official school-age population corresponding to the same level of education" (para. 1) and indicates "the capacity of the education system to enroll students of a particular age group" (para. 7). Furthermore, UIS explains that a high GER generally indicates a high participation degree and when a country's GER approaching or exceeding 100\%, that a country is, in principle, capable of accommodating all of its school-age population.

It can be seen from Figure 1 below that Indonesia has fared well in this area, always surpassing 100\% in the last decade. In fact, in average, Indonesia's GER has been higher than its neighbor countries, including Brunei, Malaysia, Myanmar, Philippines, Singapore, Thailand, and Vietnam.

\section{Figure 1. Gross Enrollment Ratio of Primary Education}

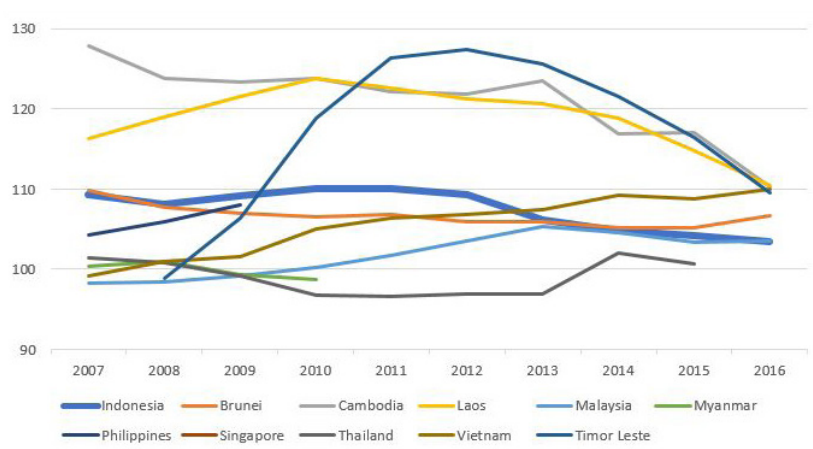

Source: World Bank (2018a)
The fact that Indonesia's GRE does not highly exceed $100 \%$ is actually a positive thing, since GER includes students of all ages, namely those whose age exceeds the official age group. Late enrollment, early enrollment, or repetition will make the total rate exceed the population of the age group that officially corresponds to the level of education, leading to GER greater than 100 percent (World Bank, 2018b). Hence, that the GERs of Cambodia and Laos are way above $100 \%$ and that Timor Leste has such a high GER rise are not necessarily good. In fact, that might be caused by misplaced enrollment.

Therefore, measuring the participation rate only through the GER is insufficient. To complement GER, we should also examine the Net Enrollment Rate (NER). According to UIS (2018b), NER is the "total number of students in the theoretical age group for a given level of education enrolled in that level, expressed as a percentage of the total population in that age group" (para. 1) and a high NER "denotes a high degree of coverage for the official school-age population" (para. 5). UIS explains that when GER is compared to NER, their difference could show the case of under-aged and over-aged enrollment, exposing the proportion of children not enrolled at the corresponding level of education.

\section{Figure 2. Net Enrollment Rate of Indonesia's Primary Education}

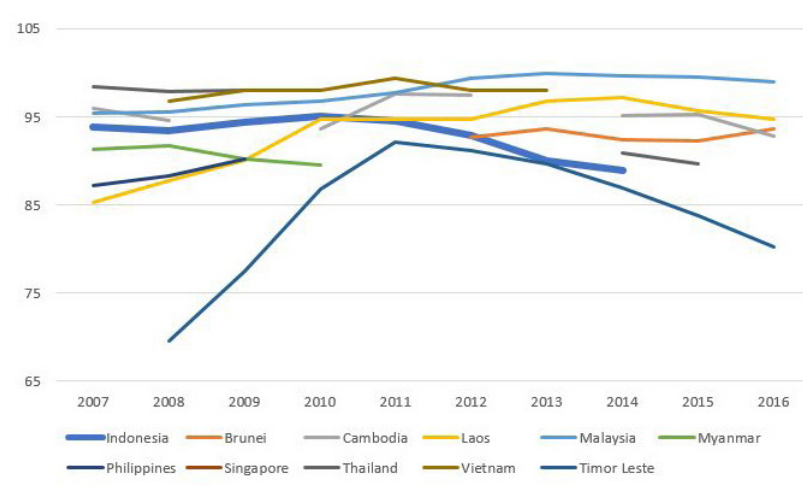

Source: World Bank (2018a)

As visible in Figure 2 above, the Indonesian government has done relatively good job in this area. During the past decade, the NER has generally been as high or even higher than 90\%, except in 2013 and 2014 (Data not available for 2015). In 2010, the rate even reached $95 \%$. Although the rate has slightly declined ever since, the latest known data in 2016 went as high as $90.88 \%$.

Compared to other SEA countries, Indonesia's NER is not significantly higher nor lower. Furthermore, 
Figure 3. Gross Enrollment Ratio of Secondary Education

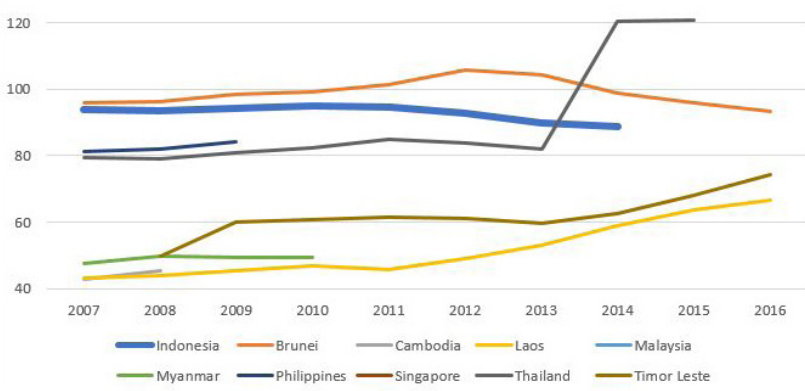

Source: World Bank (2018a)

the discrepancy between its GER and NER is not too wide either. This shows that Indonesia has got little misplaced enrollment.

All in all, in can be said that in the area of primary education, the Indonesian government has succeeded in extending its service to majority of its children.

\section{Participation Rate in Secondary Education}

The evaluation of participation rate could continue to the second education level. As can be seen in Figure 3, the Indonesian government has also fared well in extending the access to secondary education.

Since 2007 until 2016, Indonesia's GER has always been around $90 \%$. The lowest was in $2014(88.87 \%)$, while the highest was in 2011 (94.44\%). When compared to other SEA countries, only Brunei managed to surpass Indonesia. Meanwhile, Thailand only managed to do so recently, by 2013. However, the GERs of other countries are all below Indonesia.

This data can be further confirmed by examining the NER of Indonesian secondary education discussed in Figure 4.

As can be seen in Figure 4 above, the Indonesian NER generally constantly rises over the decade, reaching its highest in 2015 with the score of $76.8 \%$. Like the GER, only Brunei's and Thailand's NER in secondary level could exceed Indonesia's, while the rest are all below Indonesia's.

Therefore, it can be concluded that in average, the Indonesian government has done a remarkable job in providing access to secondary education.

\section{Student-Teacher Ratio}

Another area in which the Indonesian government has
Figure 4. Net Enrollment Rate of Indonesian Secondary Education

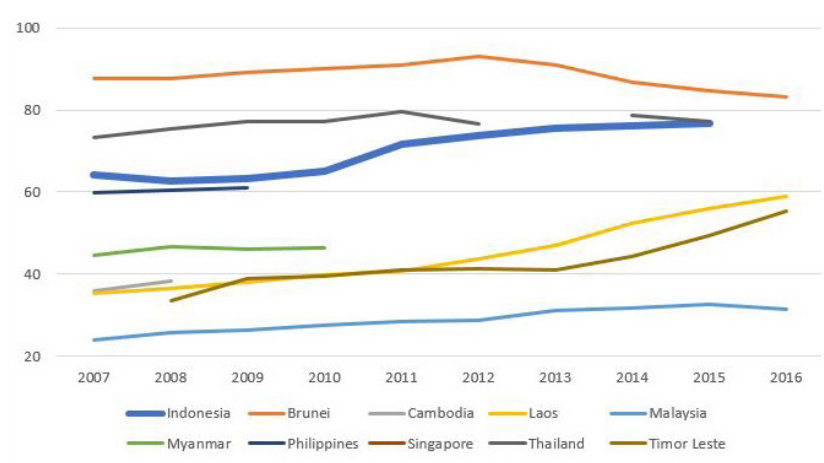

Source: World Bank (2018a)

done exceptional job is maintaining a low ratio between students and teachers.

It should be noted that small student-teacher ratio does not necessarily indicate equal distribution of teachers. Such data would not reflect the situation in every classroom; these figures only reflect the comparison between the total number of teachers and students in the whole country. Although the total number of the teachers is big, the distribution of teacher in Indonesia remains a problem until now, leaving unequal proportion of teacher availability in different areas in Indonesia (Jalal et al., 2009). Nevertheless, with such a low rate the data indicates that Indonesia does not lack of teachers.

As can be seen in Figure 5 below, Indonesia's student-teacher ratio has generally been low, almost always less than 20. It means that for every teacher, there are only around 20 students. The ratio constantly decreases, reaching its lowest in 2016 with the score of 14.

Figure 5. Student-Teacher Ratio in Primary Education

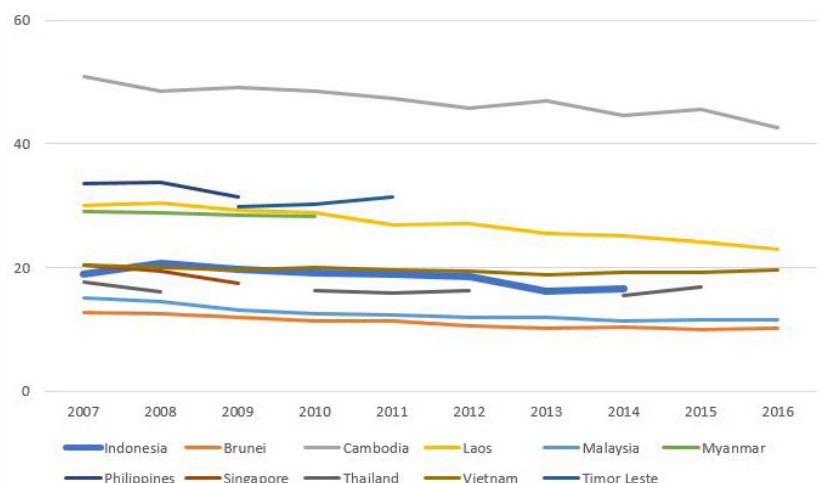

Source: World Bank (2018a) 
More SEA countries have higher STR than Indonesia, namely, Cambodia, the Philippines, Timor Leste, Laos, Myanmar, and Vietnam. While Malaysia, Brunei, and Singapore manage to maintain lower STR, it should be noted that those countries have much smaller number of students or population in general. Hence, compared to those countries, Indonesia's achievement in this area is more remarkable.

This positive trend continues to the secondary education level. As visible in Figure 6 below, Indonesia has also performed well in this particular aspect.

\section{Figure 6. Student-Teacher Ratio in Secondary Education}

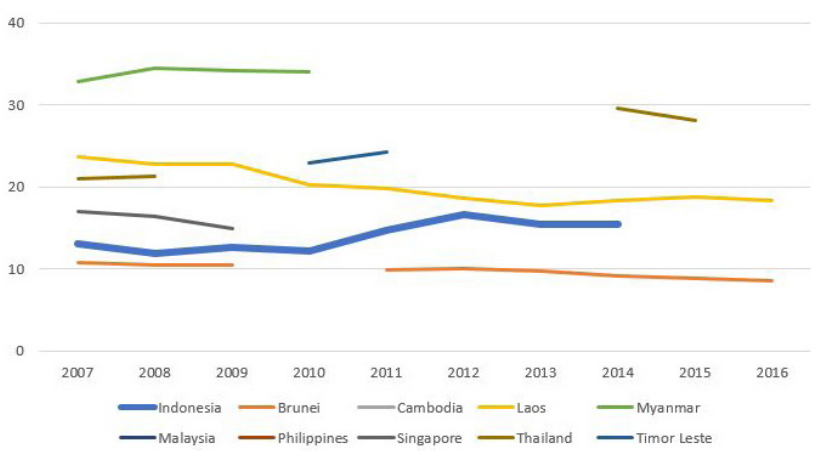

Source: World Bank (2018a)

Figure 6 above shows that Indonesia's studentteacher ratio never exceeds 17 , meaning that for every one teacher there are fewer than 17 students to handle. Achieving the lowest in 2008 with the score of 12 but hitting the highest in 2012 with the score of 16.6, the Indonesia's STR for secondary education have always been favorably low.

In comparison, the other SEA countries have not managed to maintain the positive trend. Only Brunei managed to keep low STR. Meanwhile, the other countries generally always have higher STR than Indonesia in the secondary education level.

Many more indicators can be used to evaluate the condition of Indonesia's education and this single paper would be inadequate to cover them all. However, these several measurements could show us more positive sides of Indonesia's education. Evaluated through different education indicators, the Indonesian government's work on its homework is seemingly on track.

\section{Through Its Sociocultural and Political Influence}

Nonetheless, this paper argues that the success of education should also be measured through its impacts toward the sociocultural and political situation. With a population numbering around 266.79 million, Indonesia is the world's 4th most populous country in the world after China, India, and the United States (World Population Review, 2018). Indonesia's huge population is very diverse, divided by ethnicity and faith. While these diversities have been valuable assets for Indonesia's cultural richness, more often than not they have also become triggers for multiple conflicts.

\section{Indonesia's Diversity}

World Population Review (2018) records that Indonesia has more than 300 distinct ethnic and linguistic groups, with Javanese being the largest, comprising more than $40 \%$ of the population. Other major ethnic groups include Sundanese, Bataknese, Madurese, and Betawi. Further details of the 10 major ethnic groups are provided in Table 4 below.

Table 4. Indonesia's Ethnic Diversity

\begin{tabular}{|c|l|c|}
\hline No. & Ethnic Group & Percentage (\%) \\
\hline 1 & Javanese & 42.65 \\
\hline 2 & Sundanese & 15.5 \\
\hline 3 & Bataknese & 3.58 \\
\hline 4 & Madurese & 3.03 \\
\hline 5 & Betawi & 2.88 \\
\hline 6 & Minangkabau & 2.73 \\
\hline 7 & Bantenese & 1.97 \\
\hline 8 & Banjarese & 1.74 \\
\hline 9 & Balinese & 1.67 \\
\hline 10 & Makasserese & 1.13 \\
\hline
\end{tabular}

Source: World Population Review (2018)

In addition, Simons and Fennig (2018) in Ethnologue listed that there are 719 individual languages in Indonesia, of which 707 are living while 12 are extinct.

Meanwhile, religion plays a very important and unique role in Indonesian society. According to Indonesia Investments (n.d.), albeit a secular democratic country, Indonesia is the world's most populous Muslim-majority country, with over $87 \%$ of their citizens professed a Muslim on the 2010 census. Indonesia's constitution guarantees that all people are entitled to the freedom of worship - each according to his or her own religion or belief - but, it also stipulates that the state shall be based upon the belief in "the one and only God" (as dictated in the first principle of the state's philosophy, Pancasila), 
and thus everyone must belong to a religion. Atheism is not allowed and is considered as an unacceptable ideology in the country. Another peculiarity of the Indonesian government's stance on the freedom of religion is that it recognizes only six official religions. Besides Islam, the rest of Indonesians belong to Protestantism (6.9\%), Catholicism (2.9\%), Hinduism (1.7\%), Buddhism (0.7\%) and Confucianism (0.05\%).

Regardless of the Indonesian government's effort to provide equal treatment for every group in the society, unbalanced power structure between different group identities still emerge in different sectors, such as economy or politics. World Population Review (2018) mentioned that while being a minority group in Indonesia-only about $3 \%$ of the population - the Chinese Indonesians “are influential, controlling most of the country's wealth and commerce" (para. 4). In conformity, Pisani (2014) explains that the Chinese Indonesians are "universally wealthy and are seen by many as leeches, but they provide the capital and business skills that keep the economy growing" (p. 44). Meanwhile, the dispatches of Javanese to other islands through Soeharto's past transmigration program, which were initially intended to "Indonesianize" other islands, have backfired, resulting in jealousy or anger of the locals who feel threatened by the newcomers and sometimes even ascending to physical, if not bloody, clashes (Pisani, 2014). Obviously more attempts have to be made to integrate the diverse nation into a unity.

\section{Religious Radicalization Threat}

One threat that could potentially harm Indonesia's unity is religious radicalization. In fact, religious radicalization has manifested itself in multiple terrorism attacks taking place in several places in Indonesia recently. On May 8-10, 2018, pro-ISIS inmates took over a detention facility at the paramilitary police's headquarters south of Jakarta, ultimately taking the lives of five police officers (Sholih, 2018). Then, on the morning of May 13, 2018, suicide bombers from three groups of a family- the father; the mother and the two daughters; and the two sons - attacked three churches in Indonesia's secondlargest city Surabaya, killing twelve people and injuring 40 people (Faridz, McKirdy, \& Mackintosh, 2018). Later that day, a bomb, which was supposedly used to hit another target, exploded prematurely, killing another group of family terrorist (Aji, 2018). The following day, on May 14, 2018, yet another bombing hit the police headquarter in Surabaya, injuring four police officers and six civilians (Boediwardhana, 2018). Meanwhile, on May 16,2018 , four men, who were members of a terror group called the Indonesian Islamic State, were shot dead after they attacked the Riau provincial police headquarters in Pekanbaru, using samurai swords (Soeriaatmadja, 2018; McKirdy, 2018). These bursts of terrorism actions clearly show that the danger or religious radicalization, although seemingly had diminished in the past, has actually persisted and still thrived.

\section{Religious and Racial Prejudice in 2017 Jakarta Governor Election}

Besides terrorism attacks, religious and racial prejudice has also manifested itself in the political sphere and the last Jakarta governor election in 2017 was arguably one of the worst examples, in spite of some parties' denial. Supriatma (2017) depicted how brutal the election was as he noted the disappearance of rational and civilization in the substitute of the most transparent desire for power, whereas Arifianto (2017) detailed several tensions during the campaign up to the end of the election. The result: the controversial, incumbent governor, Basuki Tjahaja Purnama-more commonly known as Ahok-lost to the contender, Anies Baswedan. On one hand, according to Pepinsky (2017), Ahok is a "double minority": a Christian in a country with Muslim majority and of Chinese descent in a country where the ethnic Chinese minorities have long faced persecution and discrimination for being perceived as generally wealthier than other Indonesians. On the other hand, the winner, Anies Baswedan was not shy to exploit religious discourse. Pepinsky explained how Baswedan cunningly grabbed the Muslims' vote by exposing and nurturing the sentiment that Muslims could not vote for a Christian. Baswedan also befriended the Islamic Defenders Front (Front Pembela Islam or FPI), a hard-liner Islamist group, which had staged multiple baseless demonstrations against Ahok for fraud blasphemy case (Wijaya \& Yosephine, 2016).

Pepinsky (2017) concluded that the Ahok case has shown the shift from Islam as a spiritual platform to a political identity, which is strongly influential for political gain and warned us of its long-lasting implications. Arifianto (2017) concurred this, claiming that “Anies' victory is another sign of the growing Islamization of Indonesian politics".

\section{Growing Conservatism and Populism}

Jakarta election was no more than a prelude for growing religious conservatism and populism. Rogers (2017), reporting several discriminatory cases, spoke that Indonesia should no longer be considered a role model of a Muslim-majority democracy that is moderate and pluralistic. In Magdalene, Diani (2018) reported the alarming increase of intolerance in Indonesian schools 
and universities, as many public schools in Java and Sumatra have now obliged their students to wear more "Islamic" attires while public universities are laden with conservative, intolerant, and radical discourses. Similarly, Arifianto (2017) reported few phenomena that can be frequently seen in the Indonesian society nowadays, such as the proliferation of Indonesian women wearing veils (hijab); the promotion of Islamist prayer groups and study circles in public university campuses; the local prohibition of alcoholic consumption; and the threat against the rights of religious minorities.

In her report, Diani (2018) also provided findings of various studies. For example, a national survey on diversity from The Center of Studies of Islam and Society (PPIM) at the State Islamic University (UIN) Jakarta in September-October 2017 found that $58.5 \%$ of Muslim students hold radical religious opinion, 34.3\% are intolerant of non-Muslims, and $51.1 \%$ are intolerant of Muslim minority groups deemed heretical, such as Ahmadiyah and Shia. Meanwhile, $69.3 \%$ of the teachers/ lecturers display intolerant attitude toward Muslim minority groups, around $25 \%$ are intolerant of nonMuslims, and more than $87 \%$ agree if the government banned minority groups.

As another example, Diani (2018) cited that in September 2016, the Ministry of Education and Culture carried out a survey on senior high school students, teachers in Salatiga, Central Java, and Singkawang, Central Kalimantan, finding that $8.5 \%$ of the respondents agreed on religion replacing the state ideology, while $7.2 \%$ was in support of ISIS.

Similarly, a 2015 survey on senior high school students in Jakarta and Bandung conducted by SETARA Institute for Democracy and Peace showed that 8.5\% students agreed the country's ideology of Pancasila must be replaced with Islam, while $9.8 \%$ students supported the Islamic State (ISIS) (Setara Institute, 2016).

\section{Indonesian Society, Violence, and Peace}

Immediate, direct, and bold responses should indeed be taken in the danger of this situation. Jones (2016) demanded that the Indonesian government strongly condemn violent religiously inspired ideology/movement and take measure to stop it, as many others have also demanded the same, while Rogers (2017) has insisted that the government should repeal discriminatory laws. However, at the same time, the Indonesian government should also ponder on how to weed out the root of these social issues. As reported in Diani (2018), MarcoesNatsir - a religious anthropologist and director of Rumah Kita Kebangsaan Foundation - stated that there should be a cultural revolution by the conscientious social class, such as critical young people who could emerge by educating them and sparking more discussions. Indeed, this is another role of education that people often miss: peacekeeping and nation building.

Is Indonesia not peaceful at present? Is Indonesia not yet cohesive as a nation? To thoroughly analyze the current state of Indonesia's sociocultural and political situation, it is important to understand the contrast between Negative and Positive Peace, presented on Table 5 below.

Table 5. Negative Peace vs. Positive Peace

\begin{tabular}{|c|c|}
\hline Negative Peace & Positive Peace \\
\hline $\begin{array}{l}\text { absence of violence } \\
\text { pessimistic } \\
\text { curative } \\
\text { peace not always by } \\
\text { peaceful means }\end{array}$ & $\begin{array}{l}\text { structural integration } \\
\text { optimistic } \\
\text { preventive } \\
\text { peace by peaceful means }\end{array}$ \\
\hline
\end{tabular}

Source: Galtung (1964), Grewal (2003)

Galtung (1964) and Grewal (2003) have explained that the absence of physical violence merely denotes negative peace. What a government and a nation should aim for is the positive peace, which is only achieved when structural integration has been established. Under the definition of negative peace, different kinds of violence would still take place and government has to continuously

Table 6. A Typology of Violence

\begin{tabular}{|l|l|l|l|l|}
\hline & Survival Needs & Well-being Needs & \multicolumn{1}{|c|}{ Identity Needs } & \multicolumn{1}{|c|}{ Freedom Needs } \\
\hline Direct Violence & Killing & $\begin{array}{l}\text { Maiming } \\
\text { Sanctions } \\
\text { Misery }\end{array}$ & $\begin{array}{l}\text { Desocialization } \\
\text { Resocialization }\end{array}$ & $\begin{array}{l}\text { Repression } \\
\text { Detention } \\
\text { Expulsion }\end{array}$ \\
\hline Structural Violence & Exploitation A & Exploitation B & $\begin{array}{l}\text { Penetration } \\
\text { Segmentation }\end{array}$ & $\begin{array}{l}\text { Marginalization } \\
\text { Fragmentation }\end{array}$ \\
\hline
\end{tabular}

Source: Galtung (1990) 
combat them curatively, and most likely, not by peaceful means, such as by military counteractions. Meanwhile, when a nation has managed to achieve the positive peace, the threats of violence are countered preventively by peaceful means, such as through the education of younger generation.

Furthermore, in classifying the types of violence, Galtung (1990) taught about direct, structural, and cultural violence, as shown in Table 6.

Following this breakdown, we are taught that killing - such as, in the forms of terrorism attacks or the inmate's rebellion-is only one form of violence, classified as a direct violence against survival needs. Meanwhile, structural violence can exist in the form of discrimination, marginalization, or fragmentation. The cases of racial or religious discriminations would fall under the category of structural violence against identity and freedom needs. Hence, according to this notion, the Indonesian government has still got tremendously huge homework in achieving genuine peace and in eradicating violence thoroughly. Even more importantly, the government needs to be aware of the danger of cultural violence.

Galtung (1990) explains that:

“By 'cultural violence' we mean those aspects of culture, the symbolic sphere of our existenceexemplified by religion and ideology, language and art, empirical science and formal science (logic, mathematics) — that can be used to justify or legitimize direct or structural violence (p. 291).

Following his explanation, the first two types of violence would be justified and thus acceptable or normalized, when the society have embraced the third, the cultural violence (See Figure 7 below).

Figure 7. Triangle of Violence

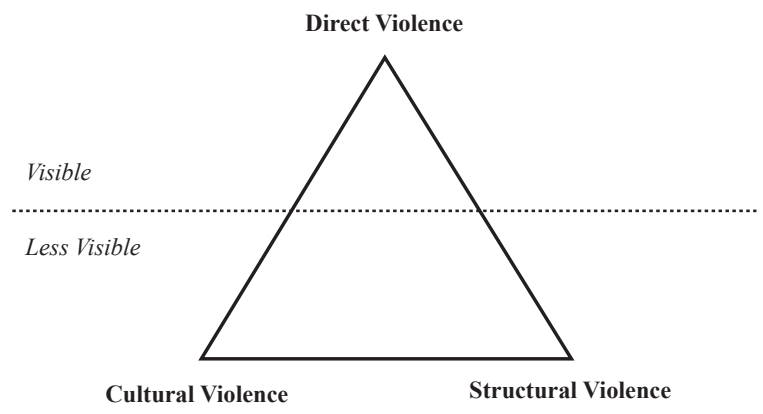

Source: Galtung (1990)

Together with structural violence, cultural violence would become a pillar for the rise of direct violence. However, even worse, when cultural violence took place, the perpetrators would not see anything wrong with their actions of structural or direct violence. To give concrete examples, any statement that justifies the spilling of blood of kafir (infidels or non-believers), or that encourages the division between pribumi (native people) and nonpribumi (non-natives) and that condones the domination of the former toward the latter, all point out cultural violence.

Looking at the latest incidents in May 2018, Indonesia is no longer exempt from physical conflicts, or direct violence. Moreover, we can make a case of the existence of structural violence, looking at the growing conservatism and primordialism. Educational attempt should also be taken to prevent the situation in Indonesia from proceeding to the stage of cultural violence. This is where the notion of Peace Education comes into play.

\section{The Other Role of Education: Peace Education}

According to Harris (2008), "Peace education is the process of teaching people about the threats of violence and strategies for peace" (p. 11). Meanwhile, Reardon explains that "Peace education is generally defined as educational policy, planning, pedagogy, and practice that can provide learners - in any setting - with the skills and values to work towards comprehensive peace." (1988; as cited in Bajaj, 2008, p. 1).

This field itself is very vast, including human rights education, conflict resolution education, global citizenship education, disarmament education, gender education, development education, and environmental education (Harris, 2008).

In general, peace education involves methods and learning processes that include: inquiry, critical thinking, and dialogue toward greater equity and social justice (Bajaj and Chiu, 2009). Harris \& Morrison (2003) explain that as a result of such pedagogy, students will become aware of the destructive effects of violence, capable of looking for alternatives in order to manage the conflicts nonviolently, and more inclined to choose peace in responding to those conflicts. Furthermore, students could help counter a culture of violence in various fields, such as in the media, entertainment industry, politics, national policy, schools, community, and the family. This is the other role of education that is needed in order to counter the danger of conservatism in Indonesia. This is also an approach to education that Indonesian policy makers need to start to consider implementing in the national education policy.

Direct security countermeasures could deal with potential terrorist threats while political reforms might be 
able to impose structural integration. However, another measure to cut off the lingering racial or religious prejudice, to build cohesiveness, and to develop national identity is highly necessary.

\section{CONCLUSION AND RECOMMENDATION}

There are different ways to measure how successful a country's education is. Measured through the students' achievement in different international standardized tests, such as PISA and TIMSS, it is clear that Indonesia still has homework to work on. Meanwhile, evaluated by economic indicators, it was obvious that Indonesia has managed to make some notable achievement. However, this paper would argue that the success of education should also be viewed from its impacts to the sociocultural and political situation. Evaluated in this light, the recent incidents and the lingering harmful ideologies to the nation's unity have proven that Indonesia still has not excelled in completing its homework. Besides the direct counter-measures, Indonesia should employ education as a mean to maintain peace and build a cohesive nation.

Peace education, as a field of study as well as pedagogy, which focuses on these two roles, is one of the tools available to work on this notion. In the future, this other role and potential pedagogy should also make it to the Indonesian government's list of homework. Considering the influence of Indonesia's diversities to its society and recognizing the dire rise of conservatism and populism, it is even more urgent than ever to employ the other role of education that many often overlook: peacekeeping and nation building.

One possible way to incorporate peace education into Indonesia's education is perhaps by inserting its tenets into currently existing subjects in Indonesia's curriculum, such as Pendidikan Kewarganegaraan (Citizenship Education, or PKn). While principles promoted by peace education - such as, peace, tolerance, democracy, social justice, and equality - may have long existed in Indonesia's curriculum, attempts to incorporate peace education tenets into its teaching materials and pedagogy might make the inclusion of such principles more structured, tangible, and thus, more impactful.

However, further study is definitely required in order to point out why the current Indonesia's curriculum has not really succeeded in combating violence, conservatism, and radicalism, and in order to incorporate peace education thoroughly into Indonesia's national curriculum.

All in all, it could be concluded that while Indonesia's education has focused mainly on performing well in standardized testing and in increasing its achievement in different education sectors, it seems that it has failed to address the issue of nation building and peacekeeping - things that are highly crucial for a diverse nation like us. Referring back to the initial question of how the success of a country's education should be measured, this paper would contend that it should not be solely measured through numbers or statistics. Instead, the success of education should be evaluated by observing how its impacts could influence the society as a whole, whether socioculturally or politically.

\section{ACKNOWLEDGMENT}

This paper was originally written to be presented in the China-Indonesia Cultural Exchange and Educational Cooperation Seminar at Hebei Normal University, in Shijiazhuang, Hebei Province, China, on June 24, 2018. Prepared for Chinese audience, the original paper contains additional parts which provide comparison between Indonesia and China in terms of their students' performance in international standardized tests and their growth reflected in educational indicators. Those parts are not included in this submission in order to adjust this paper for wider and more general audience.

\section{REFERENCES}

Aji, M. R. (2018, May 14). Police: Sidoarjo bomb explodes accidentally. Tempo. Retrieved on June 27, 2018 from https://en.tempo.co/read/ news/2018/05/14/055918403/Police-SidoarjoBomb-Explodes-Accidentally

Arifianto, A. R. (2017, April 20). Jakarta governor election results in victory for prejudice over pluralism. The Conversation. Retrieved on June 27, 2018 from https://theconversation.com/jakarta-governorelection-results-in-a-victory-for-prejudice-overpluralism-76388?utm_source $=$ facebook\&utm medium=facebookbutton

Bajaj, M., \& Chiu, B. (2009). Education for sustainable development as peace education. Peace \& Change, 34(4), 441-455. Retrieved from http://ssrn.com/ abstract $=2143437$

Boediwardhana, W. (2018, May 14). Breaking: Another bomb attack hits Surabaya police HQ. The Jakarta Post. Retrieved on June 27, 2018 from http://www. thejakartapost.com/news/2018/05/14/breakinganother-bomb-attack-hits-surabaya-police-hq.html

Diani, H. (2018, April 25). Religious conservatism at public schools and universities leads to alarming intolerance. Magdalene. Retrieved on June 27, 2018 from https:// 
magdalene.co/news-1725-religious-conservatismat-public-schools-and-universities-lead-to-alarmingintolerance-.html

Faridz, D., McKirdy, E., \& Mackintosh, E. (2018, May 15). Three families were behind the ISIS-inspired bombings in Indonesia's Surabaya, police said. CNN. Retrieved on June 27, 2018 from https://www.cnn. com/2018/05/13/asia/indonesia-attacks-surabayaintl/index.html

Galtung, J. (1964). An editorial. Journal of Peace Research, 1(1), 1-4. http://doi. org/10.1177/002234336400100101

Galtung, J. (1990). Cultural violence. Journal of Peace Research, 27(3), 291-305. http://doi.org/10.1177/0 022343390027003005

Grewal, B. S. (2003). Johan Galtung: Positive and Negative Peace, 1-7. Retrieved from http://www. activeforpeace.org/no/fred/positive_negative_peace. pdf

Harris, I. (2008). History of peace education. In M. Bajaj, Encyclopedia of peace education (pp. 1-6). Charlotte, NC: Information Age Publishing.

Harris, I., \& Morrison, M. L. (2003). What is peace education? In Peace education (pp. 9-36). NC: McFarland \& Co.

IEA. (2018a). About us. Retrieved on June 27, 2018 from http://www.iea.nl/about-us

IEA. (2018b). TIMSS. Trends in International Mathematics and Science Study. Retrieved on June 27, 2018 from http://www.iea.nl/timss

Indonesia Investments. (n.d.). Religion in Indonesia. Retrieved on June 27, 2018 from https://www. indonesia-investments.com/culture/religion/item69

Jalal, F., Samani, M., Chang, M. C., Stevenson, R., Ragatz, A. B., \& Negara, S. D. (2009). Teacher certification in Indonesia: A strategy for teacher quality improvement. (Report No. 48578). Retrieved from http://documents.worldbank.org/ curated/en/2009/04/10582109/teacher-certificationindonesia-strategy-teacher-quality-improvement

Jones, S. (2016, November 1). Why Indonesian extremists are gaining ground? The Interpreter. Retrieved on June 27, 2018 from https://www.lowyinstitute.org/ the-interpreter/why-indonesian-extremists-aregaining-ground

McKirdy, E. (2018, May 16). 1 dead, 3 injured in sword attack on Indonesian police headquarters. CNN. Retrieved on June 27, 2018 from https://www.cnn. com/2018/05/16/asia/indonesia-samurai-swordterror-suspects-killed-intl/index.html

Mullis, I. V. S., Martin, M. O., Foy, P., \& Hooper, M. (2016). TIMSS 2015 International Results in Mathematics. Retrieved from Boston College, TIMSS \& PIRLS International Study Center website: http:// timssandpirls.bc.edu/timss2015/international-results/

UIS. (2018a). Gross enrollment ratio. Retrieved on June 27, 2018 from http://uis.unesco.org/en/glossary-term/ gross-enrolment-ratio

UIS. (2018b). Net enrollment rate. Retrieved on June 27, 2018 from http://uis.unesco.org/node/334718

OECD. (2016). PISA 2015 results (volume 1): Excellence and equity in education. Paris: OECD Publishing. http://dx.doi.org/10.1787/9789264266490-en

OECD. (2018). About OECD. Retrieved on June 27, 2018 from http://www.oecd.org/about/

Pepinsky, T. (2017, June 1). Indonesian politics has been rocked by two big developments. Now what's next? The Washington Post. Retrieved on June 27, 2018 from https:/www.washingtonpost.com/news/ monkey-cage/wp/2017/06/01/indonesian-votersdisrupted-their-political-scene-whats-next-for-thecountry/?noredirect $=$ on\&utm_term $=. \mathrm{d} 84438368 \mathrm{e} 79$

Pisani, E. (2013, December 5). Indonesian kids don't know how stupid they are. Portrait Indonesia. Retrieved on June 27, 2018 from http://portraitindonesia.com/ indonesian-kids-dont-know-how-stupid-they-are/

Pisani, E. (2013, December 7). A nation of dunces. Inside Indonesia. Retrieved on June 27, 2018 from http:// www.insideindonesia.org/a-nation-of-dunces

Pisani, E. (2014). Indonesia etc.: Exploring the improbable nation. London: Granta Books.

Pisani, E. (2016, December 8). Apparently, 42\% of young Indonesians are good for nothing. Indonesia Etc. Retrieved on June 27, 2018 from http://indonesiaetc. com/apparently-42-of-young-indonesians-are-goodfor-nothing/

Reardon, B. (1988). Comprehensive peace education. New York, NY: Teachers College Press.

Rogers, B. (2017, May 29). Stop calling Indonesia a role model: It's stopped being one. The Diplomat. Retrieved on June 27, 2018 from https://thediplomat. com/2017/05/stop-calling-indonesia-a-role-modelits-stopped-being-one/

Setara Institute. (2016, May 24). Laporan survei: Toleransi siswa SMA negeri di Jakarta \& Bandung Raya. Retrieved from https://drive.google.com/file/ d/0ByXa8DJoawcgWGJXTkpISEtPNmM/view

Sholih, M. (2018, May 9). Kericuhan berdarah berjam-jam di Mako Brimob. Tirto. Retrieved on June 27, 2018 from https://irto.id/kericuhan-berdarah-berjam-jamdi-mako-brimob-cJ9s

Simons, G. F., \& Fennig, C. D. (Eds.). (2018). Indonesia. In Ethnologue: Languages of the World, (21st ed.) [Online version]. Dallas, TX: SIL International. Retrieved on June 27, 2018 from https:/www. ethnologue.com/country/ID

Soeriaatmadja, W. (2018, May 16). 4 men attack Riau provincial police headquarters using swords, killing 
one police officer. The Straits Times. Retrieved on June 27, 2018 from https://www.straitstimes.com/ asia/se-asia/at-least-two-police-officers-hurt-inattack-on-riau-provincial-police-headquarters

Supriatma, M. (2017, April 23). Setelah kemenangan: Saran untuk kaum 'pribumi'. Indoprogress. Retrieved on June 27, 2018 from https://indoprogress. com/2017/04/setelah-kemenangan-saran-untukkaum-pribumi-2/

Wijaya, C. A., \& Yosephine, L. (2016, October 14). Thousands of hardliners march against Ahok. The Jakarta Post. Retrieved on June 27, 2018 from http://www.thejakartapost.com/news/2016/10/14/ thousands-hard-liners-march-against-ahok.html
World Bank. (2018a). Education [Data file]. Retrieved on June 27, 2018 from https://data.worldbank.org/topic/ education?locations=ID

World Bank. (2018b). How can gross enrollment ratios be over 100 percent? In World Development Indicators (WDI). Retrieved on June 27, 2018 from https:// datahelpdesk.worldbank.org/knowledgebase/ articles/114955-how-can-gross-school-enrollmentratios-be-over-100

World Population Review. (2018). Indonesia Population 2018. Retrieved on June 27, 2018 from http:// worldpopulationreview.com/countries/indonesiapopulation/ 